No. $13(17)$

\title{
U PROGU WIECZNOŚCI WIELKICH MATEMATYKÓW
}

\section{Ludomir Laudański}

Streszczenie. Skromne autorskie zamierzenie polega na spopularyzowaniu Księgi zmartych filozofów - będącej przekładem z angielskiego arcyciekawej pracy Simona Critchleya (ur. 1960) - profesora i kierownika Katedry Filozofii w New School for Social Research New York. Dane oryginału: The Book of Dead Philosophers, Vintage, First Ed. 2009, ss. 266, paper back. Polski przekład Janusza Margańskiego, Wydawca Farbiarnia, Bydgoszcz 2011, ss. 318.Termin filozof na kartach tej Księgi prezentującej szczegóły śmierci około 190 postaci - jest rozumiany szeroko: mieści się w nim i św. Augustyn, mieści się i Luter; mieszczą się też i Mikołaj Kopernik, i Tycho de Brahe (próżno by tam jednak szukać Johana Keplera, Leonharda Eulera). Poszukiwanie szczegółów mówiących o tym, jak umierali matematycy, nie jest łatwym zadaniem, zwłaszcza jeśli się weźmie pod uwagę aspekt: jaki posiadali stosunek do życia i śmierci. Tak więc moje zamierzenie ma służyć: (1) zachęcie do lektury Critchleya (najlepiej w oryginale); (2) inicjacji własnych poszukiwań - dedykowanych matematykom; (3) zachęty do refleksji nad ludzkim życiem i śmiercią.

Słowa kluczowe: matematycy, refleksje o życiu i śmierci.

JEL Classification: I29.

DOI: $10.15611 / \mathrm{dm} .2016 .13 .07$.

\section{Wprowadzenie}

Janusz Margański to niewątpliwie dobry tłumacz - ale na smak podam przykłady mające coś na rzeczy, a może na świadectwo zachęty sięgania do oryginału. Oto na s. 254 wydania oryginalnego czytamy:

I cannot deny that I have dipped my toes, and sometimes both feet up to the knees, into the unruly waters of Wikipedia. This is a vast and growing resource, which is very uneven, not always be trusted, but full of many fascinating articles and leads. 
A teraz jak sobie $\mathrm{z}$ tym fragmentem poradził tłumacz (proszę sięgnąć do s. 302):

Nie moge zaprzeczyć, że wchodzitem, czasami po kolana, w niesforne wody Wikipedii. To ogromne i stale potężniejace źródło, bardzo nierówne, nie zawsze godne zaufania, ale pelne wielu fascynujacych artykułów i tropów.

Życiorys Kopernika - krótki - Critchley w rzeczy samej kończy zdaniem, które tu przytoczę, a którego w ogóle nie ma w polskim przekładzie (cytuję za s. 110 wydania oryginalnego):

He perished as he published and published as he perished.

Wreszcie Critchley - pisząc o Erazmie z Rotterdamu na s. 106 wydania oryginalnego (polski przekład znajdziemy na s.130), tak napisał:

"The Moriae Encomium or Prise of Folly - a delightfully stinging satire, is dedicated to More and its title is a pun upon his name”.

Co polski tłumacz przełożył w sposób następujący:

"Morie Encomium czyli Pochwata gtupoty, rozkosznie jadowita satyra została dedykowana More'owi, a jej tytuł to kalambur oparty na jego nazwisku”.

Tu ostrze mojej inwencji zwraca się nie tyle ku autorowi przekładu - co $\mathrm{ku}$ autorowi oryginału (bądź nawet $\mathrm{ku}$ im obydwu). Otóż posiadamy w domowym księgozbiorze dwa egzemplarze Pochwały głupoty. Warto je tu pokrótce scharakteryzować. Zachowam kolejność chronologiczną. Ale na początku powiem, że oba egzemplarze kupowałem w ... kioskach, oraz to, że każdy z nich posiada obcego wydawcę. Wcześniejszy tomik to produkt De Agostini i Altaya - drukowany w Hiszpanii AD 2001 - we współpracy z Ossolineum. Jest to przedruk wydania Ossolineum AD 1953 z solidnym zapleczem bibliograficznym i obszernym wstępem Henryka Barycza. W rzeczy samej jest to drugie polskie wydanie - pierwsze było lwowskie AD 1875 - do dziś nie posiada zidentyfikowanego tłumacza. Wydanie Ossolineum (to kioskowe) - drugie z kolei - tłumaczył Edwin Jędrkiewicz. W tym wydaniu mamy wiarygodny - jak mniemam - tytuł dzieła, który spróbuję tu skopiować zasobami edytora Word:

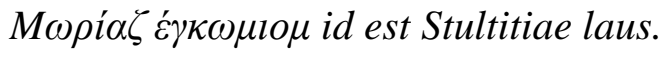

Drugi produkt - którego wydawcą jest Hachette - AD 2011 - o 10 lat młodszy. Otóż strona bibliograficzna francuskiego wydawcy jest skąpa może po to, aby zataić - tak podejrzewam - że stanowi ona kopię pierwszego 
(lwowskiego) wydania? Na tzw. stronie redakcyjnej - pod hasłem tytuł oryginału - przytoczony jest tylko pierwszy grecki człon. Nigdzie nie ma danych dotyczących przekładu. Za to strona edytorska - ekscelentna! pociągająca! książki tej serii (mam ich kilka) znajdują się wewnątrz zgrabnych pudełek (dust covers). Opisywany tomik jest 68 (tak!) w Serii Biblioteka Filozofów. Powiem trochę złośliwie, że w tej sytuacji tytuł Pochwała głupoty wygląda dziwnie à propos! Wrócę jednak do mojej zapowiedzi: otóż tytuł dzieła Erazma (komentuje to Henryk Barycz) zawiera inicjujący składnik - wyrażony w języku greckim - i drugi - przełożony na łacinę. Frazę Critchleya mówiącą o kalamburze z grą słów względem personaliów More’a należy uznać za cokolwiek niedopowiedzianą. Dowcip wymyślony przez Erazma polega na spostrzeżeniu, że z jednej strony M $\omega$ pí $\alpha$ - to głupota - a z drugiej jego przyjaciel Thomas More - który w zlatynizowanej wersji znany jest jako Morus i któremu Erazm dedykował swe dzieło - w transkrypcji fonetycznej tytułowego

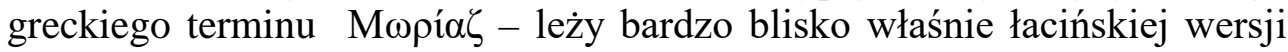
jego nazwiska.

\section{Matematycy: Kepler i Euler}

W roku 1968 sowiecki wydawca Наука opublikował broszurę Творцы высшей математики - Л. С. Фрейман Москва - с. 216. Jej autor Леон Семенович Фрейман - o którym Wikipedia podaje tylko, że był profesorem matematyki - opierając się na bibliografii liczącej 40 tytułów (wszystkie wyłącznie w języku rosyjskim), przedstawił pasjonującą pracę zawierającą prawdziwe bogactwo informacji w odniesieniu do tytułowych postaci. W niniejszym tekście przytoczę pewne fakty dotyczące dwóch matematyków mając na uwadze tytułowy aspekt mego wystąpienia na Forum 9. Konferencji „Dydaktyka Matematyki”. Mam na myśli Keplera i Eulera. Oparciem będzie przytoczona książka. Z uwagi na kuriozalne tezy, jakie tam znajdziemy, proponuję, aby były one tu przedstawione w postaci dosłownego cytatu. Zacznę jednak od informacji składających się na okoliczności śmierci Keplera. Tak więc dla nabrania smaku - oto jak opisuje Frejman okoliczności śmierci Keplera:

Осенью 1630 он предпринимает попытку (в который раз!) получить свои деньги. Это требовало поездки в Регенсбург. Чтобы уменьшить расходы, Кеплер поехал верхом (от Линца до Регенсбурга ок. 150 км). В дороге он простудился, в Регенсбурге прохоровал неделю и 5 ноября 1630 г. скончался. Его похоронили друзья-почитатели, директор гимназии и пастор. Наследство, если можно применить здесь такое 
выражение, Кеплера состояло из 22 экю (около семи копеек) носильного платья и нескольких экземпляров его сочинений, предназначеных для продажи. Эпитафию себе сочинил сам Кеплер:

Mensus eram coelos, nunc terrae metior umbras;

Mens coelestis erat, corporis umbra iacet.

Natomiast cytat, jaki szczególnie polecam Czytelnikowi tego tekstu - jest wyjęty dosłownie - linijka po linijce - ze stron 22-23 książki Frejmana. Jestem zdania, że mogę go pozostawić bez żadnych komentarzy - ale nie mogę nie dodać okrzyku, jaką to zatrutą studnię przedstawiają funkcjonujace do dziś teksty historyków sowieckich:

Было бы слишком долго перечичлять все правильные объяснения и исполнившиеся предсказания, даннные Кеплером. В совокупности они свидетельсвуют о том что был на голову выше не только рядовых современников, но и деятелей науки. И тот же человек удивительным образом верил самым антинаучным предрассудкам. Мало того, что он был глубоко религиозен и считал что открытые им законы природы способствуют прославлению божества он принимал всерьез всю христианскую мифологию, церковный ритуал и т. д. Он был не чужд и мистики чисел, на что указывает название его труда (Гармония мира) Harmonices Mundi.

Życie Leonharda Eulera (1707-1783), najbardziej pracowitego i najbardziej płodnego matematyka wszystkich czasów, nie obfitowało w dramatyczne okoliczności - tym niemniej jest to biografia która posiada obszary cechujące się cokolwiek niecodziennymi rysami. Natomiast okoliczności śmierci Eulera były - można powiedzieć - całkowicie zwyczajne. Oto jak je przedstawił Frejman (s. 181):

7 сентября 1783 г. вечером, после вполне благополучного дня, во время игры с внуком Эйлер вдруг почуствовал себя плохо и с возгласом: 'Я умираю' потерал сознание. Вскоре он скончался, или по выражению Кондорсе 'перестал жить и вычислять'.

Faktem jest, że biografie matematyków koncentrują się nie na szczegółach ich życia, lecz na ich dorobku, ideach, jakie przynosili na świat. Z tego powodu zdążanie za ideą Critchleya wymaga dostępu do źródeł archiwalnych, o jakie w Polsce jest trudno. Praca - tego rodzaju - jak przywołana monografia Frejmana - będąca wszakże tekstem kompilacyjnym - należy do szczęśliwych wyjątków, lecz i ona może ideę podniesioną przez Critchleya 
spełnić jedynie względem szczęśliwych wyjątków - do których zaliczyć można tylko pierwszą z tytułowych postaci.

\section{O refleksji życie - śmierć}

Zacytuję tu symptomatyczną opinię Critchleya, która - gdy ją poznałem przy pierwszym czytaniu - wydała mi się w większym stopniu opinią rodzącą protest, lecz pod dłuższej refleksji poczułem się zmuszony przyznać, że w tej opinii jest wiele prawdy (s. 248):

Christianity is about nothing other than getting ready to die. It is a rigorous training for death, a kind of death in life that places little value on longevity. Christianity, in the hands of Paul, and Augustine or Luther, is a way of becoming reconciled to the brevity of human life and giving up the desire for wealth, worldly goods and temporal power. Nothing is more inimical to most people who call themselves Christians than true Christianity. This is because they are actually leading quietly desperate atheist lives bounded by a desire for longevity and terror of annihilation.

Wreszcie też - może jeszcze jeden cytat - tym razem zapożyczony ze wstępnego rozdziału zatytułowanego To Die Laughing - a tytuł ten Margański przekazał bardziej rozwiniętą frazą: Umrzeć z uśmiechem na ustach. Oto jego wersja:

Mój własny pogląd na śmierć jest bliski poglądowi Epikura znanemu jako czteroczęściowa terapia: Boga się nie bój, śmiercią się nie przejmuj, to, co dobre łatwo osiągniesz, to, co straszne, łatwo przetrzymasz. W zakończeniu czterech istniejących przypisywanych mu listów pisze:

Staraj się oswoić z myślą, że śmierć jest dla nas niczym, albowiem wszelkie dobro i zło wiąże się z czuciem; a śmierć jest niczym innym, jak właśnie całkowitym pozbawieniem czucia. Przeto owo niezbite przeświadczenie, że śmierć jest dla nas niczym, sprawia, że lepiej doceniamy śmiertelny żywot, a przy tym nie dodaje bezkresnego czasu, lecz wybija nam $\mathrm{z}$ głowy pragnienie nieśmiertelności ${ }^{13}$. 
A oto wersja oryginalna - jak ją zapisał Critchley:

My own view of death is closer to that of Epicurus and what is known as the four-part cure: don't fear God, don't worry about death, what is good is easy to get, and what is terrible is easy to endure. He writes in the final of the four extant letters attributed to him:

Get used to believing that death is nothing to us. For all good and bad consists in sense-experience, and death is the privation of sense-experience. Hence a correct knowledge of the fact of death makes the mortality of life a matter of contentment, not by adding a limitless time to life but by removing the longing for immortality.

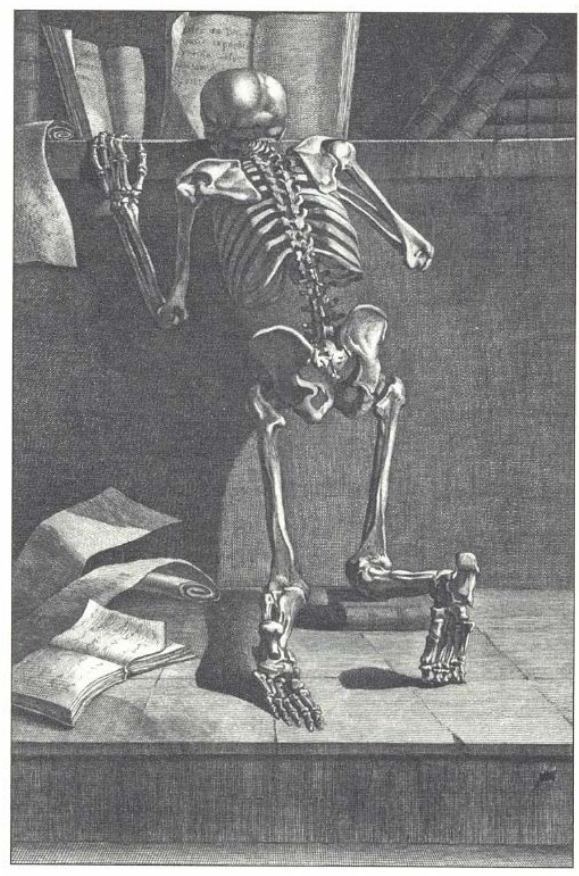

